\title{
Foraging responses of Antarctic fur seals to changes in the marine environment
}

\author{
Dominic J. McCafferty*, Ian L. Boyd, Tony R. Walker, Robert I. Taylor \\ British Antarctic Survey, Natural Environment Research Council, High Cross, Madingley Road, \\ Cambridge CB3 0ET, United Kingdom
}

\begin{abstract}
This study examined the relative contribution of environmental variation and the seasonal demands of pup rearing on the foraging behaviour of female Antarctic fur seals Arctocephalus gazella al Bird Island, South Georgla $\left(54^{\circ} \mathrm{S}, 38^{\circ} \mathrm{W}\right)$, during 3 austral summers (1994 to 1996). Time-depth recorders measured the diving behaviour of 72 individuals during a total of 385 foraging trips totalling $1964 \mathrm{~d}$ at sea. The frequencies of krill, fish and squid in the diet were estimated from prey items contained in scats. In 1996, a year of high krill abundance, females made shorter foraging trips, fewer dives and spent more time ashore than in 1994 when krill was scarce. Females fed exclusively on krill in 1996, and frequent shallow daytime diving indicated that krill were close to the surface during the day. In 1994 and 1995 deeper and longer-duration daytime dives were associated with a higher proportion of fish and squid in the diet. Foraging trip duration, ashore duration and dive frequency increased through the course of the 1995 and 1996 lactation seasons. Females, therefore, appeared to match pup demands by increasing both time feeding at sea and energy delivery to the pup on land. However, the importance of sea surfacc temperature ardu durativn uf ulght in muitipie regression models suggested that physical factors were also important in explaining the seasonal pattern of fur seal foraging behaviour.
\end{abstract}

KEY WORDS: Foraging · Antarctic fur seal - Environmental variation · Seasonality $\cdot$ Krill

\section{INTRODUCTION}

An animal's foraging behaviour will be constrained, within limits, by morphological and physiological specialisations for feeding (Illius \& Gordon 1993, Wainwright 1994). Within these limits, however, many animals show considerable variation in foraging because of differences in the distribution and abundance of food, changes in demand for resources during reproduction or fluctuations in abiotic conditions (e.g. Clutton-Brock et al. 1982). For large and wide-ranging marine animals it is not possible to conduct experiments that examine the response of an animal to individual factors such as prey distribution or abundance. However, it may be possible to determine how these animals respond to differences in food availability, resource demands and abiotic conditions in environments that exhibit distinct annual and seasonal change.

-E-mail: d.mccafferty@bas.ac.uk
One group of organisms that may be suited to this type of investigation are the fur seals (otariids) that rely on productive ocean currents to provide food or breed in highly seasonal ecosystems (Gentry \& Kooyman 1986). In both cases, changes in oceanographic circulation appear to be responsible for fluctuations in prey abundance which cause major reproductive failure (Croxall et al. 1988, Trillmich et al. 1991). This provides an opportunity to distinguish between variation in foraging behaviour that is caused by changes in resource demands during breeding and differences that are due to environmental factors.

In common with other species of fur seals, Antarctic fur seals Arctocephalus gazella exhibit a foraging attendance cycle in which females feed at sea for 3 to $5 \mathrm{~d}$ and return to suckle their pup for 1 to $2 \mathrm{~d}$ during 4 mo of lactation (Doidge et al. 1986).

Previous studies show that fur seals increase the total quantity and energy content of milk delivered to the pup throughout lactation (Arnould \& Boyd 1995a, 
Arnould et al. 1996) and during lactation the diet of Antarctic fur seals consists mainly of Antarctic krill Euphausia superba (Croxall \& Pilcher 1984, Doidge \& Croxall 1985, Reid \& Arnould 1996). The pattern of foraging behaviour is closely matched to the diel migration of krill to the surface at night (Croxall et al. 1985) and to the spatial distribution of krill swarms (Boyd 1996). In years of low krill abundance there is high mortality, low growth rate and low weaning mass of pups. Therefore, it appears that fur seals increase their foraging trip duration to gain sufficient energy for lactation (Croxall et al. 1988, Lunn et al. 1994).

We predict that Antarctic fur seals must increase their foraging effort to cope with annual changes in krill availability and must also increase their effort throughout lactation to match the increasing energy demands of the pup. The aims of this study were therefore to determine (1) the relationship between foraging behaviour and diet in relation to annual variation in the marine environment and (2) how foraging behaviour responds to the increasing demands of pup growth during lactation.

\section{MATERIALS AND METHODS}

Study seals and instruments. The diving behaviour of female Antarctic fur seals was studied at Bird Island, South Georgia $\left(54^{\circ} \mathrm{S}, 38^{\circ} \mathrm{W}\right)$, during 3 austral summers, 1993/94, 1994/95 and 1995/96 (referred to as 1994, 1995 and 1996). Study seals were selected opportunistically from the breeding colony, and each year an attempt was made to recapture previously instrumented seals. Fiftyfive percent of females were initially captured 1 to $2 \mathrm{~d}$ postpartum and the remainder were caught throughout the season. In 1994 females were captured from 17 December onwards, but in 1995 and 1996 captures were started on 21 and 29 November, respectively.

Study seals were captured and restrained as described by Gentry \& Holt (1982). On first capture, a lower post-canine tooth was removed for age determination (Arnbom et al. 1992) and the seal was tagged with a numbered plastic tag (Dalton Supply Ltd, Henley-on-Thames, UK) on the trailing edge of both foreflippers. Body mass $( \pm 0.5 \mathrm{~kg})$ and body length $( \pm 0.5 \mathrm{~cm})$ were recorded when seals were caught. To relocate study seals and to monitor attendance ashore (ashore duration) a $40 \mathrm{~g} 165 \mathrm{MHZ}$ radio-transmitter (Sirtrack Ltd, Havelock North, New Zealand) was attached to the fur on the mid-dorsal surface using quick set epoxy adhesive (RS Ltd, Corby, Northants, UK). Radio-transmitters were removed prior to moult during the final stages of lactation or if pups were known to have died. Time-depth recorders (TDR Mk3, Mk5 and Mk6, Wildlife Computers Inc., Redmond,
USA) were used to study diving behaviour and were deployed for 10 to $14 \mathrm{~d}$. Mk3 and Mk5 devices were attached with plastic cable ties to a nylon webbing strap $(10$ to $15 \times 2.5 \mathrm{~cm})$ that had been glued to the mid-dorsal fur. This method allowed rapid removal of the device and allowed TDRs to be redeployed on the same individual throughout the season. Mk6 devices were glued directly onto the fur and removed by clipping the hair from around the instrument.

On first capture with their mothers, pups were marked by a number bleached on the dorsal fur with peroxide hair dye (Bristol-Myers Ltd, Uxbridge, UK). Prior to full moult (around $6 \mathrm{wk}$ old) pups were tagged. Pups were recaptured at 1 to $2 \mathrm{wk}$ intervals to measure body mass $( \pm 0.5 \mathrm{~kg})$ and body length $( \pm 0.5 \mathrm{~cm})$. Daily checks of suckling locations were made during March and April and the weaning date was taken to be the date when mother and pup were last seen together. Pup growth rates and body size at weaning were estimated by linear regression.

Diet. Diet was examined by collecting 10 scats each week from the breeding beach where seals were captured. Scats were trozen at $-20^{\circ} \mathrm{C}$ for subsequent analysis. The presence of krill, fish and squid was recorded and krill size was estimated from the length of approximately 20 intact carapaces from each scat (Reid \& Arnould 1996).

Data collection and analysis. Radio-transmitter signals were monitored with 2 automated receiving stations close to the breeding beach (Boyd et al. 1991) and females were located using a portable receiver and Yagi antenna. TDRs were programmed to sample depth $( \pm 1 \mathrm{~m})$ at $10 \mathrm{~s}$ intervals and temperature $\left( \pm 0.1^{\circ} \mathrm{C}\right)$ at $300 \mathrm{~s}$ intervals (not available on Mk3). Data from the TDR were transferred to computer and decoded using custom-written software (Boyd et al. 1997) to produce an ASCII listing of the data and analysis of individual dives $\geq 1 \mathrm{~m}$. A foraging trip was considered to occur when the TDR recorded wet readings for more than $12 \mathrm{~h}$ (Boyd et al. 1991). The time at sea was divided into travel and foraging periods. Outward travel occurred until an animal made a minimum bout of 3 dives (i.e. 3 dives, ea.ch $\geq 10 \mathrm{~m}$, within $10 \mathrm{~min}$ ) following departure from the colony (Boyd et al. 1991). Foraging was judged to start from this time and continue until the final minimum diving bout occurred. The period between the last bout and arrival ashore was considered to be return travel. Foraging statistics were calculated only from dives that occurred during the foraging period ( $95 \%$ of total dives at sea).

Mean sea surface temperature (SST) during each trip was calculated from night-time records when the maximum depth during the previous 5 min did not exceed $20 \mathrm{~m}$. This excluded periods when diurnal increases in temperature were recorded due to solar 
heating of the TDR when animals spent long periods at the surface (McCafferty unpubl. data). Independent measurements of mean monthly SST, blended from ship, buoy and bias-corrected satellite data (Reynolds \& Smith 1994), were obtained from the Integrated Global Ocean Services System (IGOSS) database, which was accessed via the Internet (http://ingrid. ldgo.columbia.edu). The area investigated was an area of $6^{\circ}$ latitude $\times 6^{\circ}$ longitude centred at $54^{\circ} \mathrm{S}, 38^{\circ} \mathrm{W}$ (see Fig 5). Data were available at a resolution of $1^{\circ} \times 1^{\circ}$ and were averaged for the entire area $(n=36)$.

The duration of night was determined as the time between dusk and dawn (i.e. nautical twilight: when the sun was midway between $6^{\circ}$ and $12^{\circ}$ below the horizon). Dawn and dusk occurred at 05:50 h GMT (range 04:40 to $07: 50 \mathrm{~h}$ ) and 23:20 h GMT (23:20 to $00: 15 \mathrm{~h}$ ), respectively. The duration of night averaged $6.6 \mathrm{~h}$, reaching a minimum of $4.6 \mathrm{~h}$ at midsummer and a maximum of $10.6 \mathrm{~h}$ by the end of March.

Statistics. Many individuals were followed throughout the entire breeding season and in some cases the same individuals were studied in different years. This meant that observations were not independent within or between years. However, a Student's t-test (pairwise comparison) was used to compare the foraging behaviour of individuals between years. To ensure that interannual comparisons were made between similar stages of the season, foraging trips from one year were matched with trips from another if their start dates were less than 2 wk apart. A repeated measures ANOVA. was also used to test for differences within years

A 3-way ANOVA was used to examine the main effects of year, instrument type and maternal characteristics on individual foraging behaviour. Models were computed with the SAS GLM procedure using Type III tests (partial sums of squares) that are insensitive to the order in which variables are added (SAS Ver. 6.11; SAS Institute Inc., Cary, USA). Female age was divided into 2 age classes based on the age of primiparity $(\leq 6$ yr old) and multiparity ( $>6$ yr old) (Lunn et al. 1994). Females that were not aged were excluded from the analysis, and in cases where females were sampled in more than 1 year, data from 1 year was selected at ran$\operatorname{dom}(\mathrm{n}=55)$.

Multiple regression (as described by Brown \& Rothery 1993) was used to examine the seasonal change in foraging behaviour. This method examined the contribution of multiple inter-correlated variables by determining all possible combinations of variables in gen- eral linear models. In all models, female identity, year, instrument type and female age class were included as factors, and pup age, pup body mass, duration of night and SST (measured by TDRs) were entered as explanatory variables. Models used the mean SST measured by TDRs during each foraging trip because this was thought to be more representative of temperatures experienced by females when foraging. Only foraging trips from aged females were included, therefore the analysis was based on 291 foraging trips.

\section{RESULTS}

\section{Study seals}

TDRs were successfully deployed on 72 individuals, 26 of which were instrumented in more than 1 year. Mk3 TDRs were deployed on 8 and 15 individuals in 1994 and 1995 respectively. Mk5s were fitted to 15,26 and 22 individuals in 1994, 1995 and 1996, and Mk6s were deployed on 21 and 3 individuals in 1995 and 1996 respectively.

Females were, on average, 7.9 yr old (95\% confidence interval 7.3-8.6) and had a mean body mass of $37.9 \mathrm{~kg}(37.0-38.8)$, a mean length of $127.2 \mathrm{~cm}(126.3-$ 128.1 ) and a mean condition index of $0.296 \mathrm{~kg} \mathrm{~cm}^{-1}$ (0.291-0.302). There was a signifirant difference in age, body mass and condition of females between years (ANOVA p $<0.05$ in all cases) but there was no difference in body length $(\mathrm{p}=0.18)$ (Table 1). Study seals in 1994 were on average 2 yr younger and their body mass was $8 \%$ less than in 1995. Females in 1994 were also $6 \%$ poorer in condition than in the subsequent 2 years.

Table 1. Mean ( $\pm 95 \%$ confidence interval) body mass, length and condition and age of female Antarctic fur seals. $\mathrm{n}$ is number of seals measured and aged, respectively. Differences between means were significant $(\cdot)$ at $p<0.05$ (Student's $t$-test); ns: not significant

\begin{tabular}{|c|c|c|c|c|c|c|}
\hline Year & $\begin{array}{l}\text { Mass } \\
(\mathrm{kg})\end{array}$ & $\begin{array}{l}\text { Length } \\
(\mathrm{cm})\end{array}$ & $\begin{array}{l}\text { Condition } \\
\left(\mathrm{kg} \mathrm{cm}^{-1}\right)\end{array}$ & $\mathrm{n}$ & $\begin{array}{l}\text { Age } \\
\text { (yr) }\end{array}$ & $\mathrm{n}$ \\
\hline 1994 & $\begin{array}{c}35.9 \\
(34.0-37.8)\end{array}$ & $\begin{array}{c}126.3 \\
(124.4-128.2)\end{array}$ & $\begin{array}{c}0.282 \\
(0.272-0.293)\end{array}$ & 23 & $\begin{array}{c}6.6 \\
(5.6-7.7)\end{array}$ & 22 \\
\hline 1995 & $\begin{array}{c}38.7 \\
\{37.5-40.0\}\end{array}$ & $\begin{array}{c}128.1 \\
(126.8-129.3)\end{array}$ & $\begin{array}{c}0.301 \\
(0.293-0.309)\end{array}$ & 50 & $\begin{array}{c}8.6 \\
(7.7-9.5)\end{array}$ & 38 \\
\hline 1996 & $\begin{array}{c}38.2 \\
(36.4-40.0)\end{array}$ & $\begin{array}{c}126.4 \\
(1.24 .5-128.2)\end{array}$ & $\begin{array}{c}0.301 \\
(0.290-0.312)\end{array}$ & 25 & $\begin{array}{c}8.2 \\
(7.1-9.4)\end{array}$ & 23 \\
\hline All years & $\begin{array}{c}37.9 \\
(37.0-38.8)\end{array}$ & $\begin{array}{c}127.2 \\
(126.3-128.1)\end{array}$ & $\begin{array}{c}0.296 \\
(0.291-0.302)\end{array}$ & 98 & $\begin{array}{c}7.9 \\
(7.3-8.6)\end{array}$ & 83 \\
\hline \multicolumn{7}{|c|}{ Differences between means } \\
\hline 1994 vs 1995 & $\cdot$ & ns & $\cdot$ & & $\cdot$ & \\
\hline 1994 vs 1996 & ns & ns & $\cdot$ & & ns & \\
\hline 1995 vs 1996 & ns & ns & ns & & ns & \\
\hline
\end{tabular}


Table 2. Mean foraging trip statistics ( $\mathrm{n}=$ number of trips) of female Antarctic fur seals ( $\pm 95 \%$ confidence interval). Trip durations were highly skewed and are therefore expressed as medians. The median dive depth and median dive duration for each trip were calculated and averaged for each year. Kruskal-Wallis test and Student's t-test tested for differences in medians and means, respectively. Differences between medians and between means were significantly different $(\cdot)$ at $p<0.05$; ns: not significant

\begin{tabular}{|c|c|c|c|c|c|c|c|c|c|c|c|}
\hline Year & $\mathrm{n}$ & $\begin{array}{l}\text { Trip } \\
\text { duration } \\
\text { (d) }\end{array}$ & $\begin{array}{l}\text { Ashore } \\
\text { duration } \\
\text { (d) }\end{array}$ & $\begin{array}{c}\text { Outward } \\
\text { travel } \\
\text { (h) }\end{array}$ & $\begin{array}{l}\text { Return } \\
\text { travel } \\
\text { (h) }\end{array}$ & $\begin{array}{l}\text { No. of } \\
\text { dives }\end{array}$ & $\begin{array}{l}\text { Dive } \\
\text { depth } \\
\text { (m) }\end{array}$ & $\begin{array}{c}\text { Dive } \\
\text { duration } \\
\text { (s) }\end{array}$ & $\begin{array}{c}\text { Dive } \\
\text { trequency } \\
\text { (dives } \mathrm{h}^{-1} \text { ) }\end{array}$ & $\begin{array}{c}\% \text { time } \\
\text { sub- } \\
\text { merged }\end{array}$ & $\begin{array}{c}\% \text { dives } \\
\text { at } \\
\text { night }\end{array}$ \\
\hline 1994 & 29 & $\begin{array}{c}6.8 \\
(2.2-16.6)\end{array}$ & $\begin{array}{c}1.4 \\
(1.1-1.7)\end{array}$ & $\begin{array}{c}7.7 \\
(6.2-9.5)\end{array}$ & $\begin{array}{c}7.1 \\
(5.4-9.1)\end{array}$ & $\begin{array}{c}3489 \\
(2998-4017)\end{array}$ & $\begin{array}{c}11.8 \\
(9.2-14.9)\end{array}$ & $\begin{array}{c}66.2 \\
(58.7-73.7)\end{array}$ & $\begin{array}{c}17.9 \\
(16.2-19.8)\end{array}$ & $\begin{array}{c}35 \\
(32-38)\end{array}$ & $\begin{array}{c}61 \\
(55-67)\end{array}$ \\
\hline 1995 & 177 & $\begin{array}{c}5.5 \\
(0.8-11.1\}\end{array}$ & $\begin{array}{c}1.8 \\
(1.6-1.9)\end{array}$ & $\begin{array}{c}5.6 \\
(5.1-6.1)\end{array}$ & $\begin{array}{c}6.3 \\
(5.6-7.0)\end{array}$ & $\begin{array}{c}1822 \\
(1676-1974)\end{array}$ & $\begin{array}{c}11.4 \\
(10.3-12.6)\end{array}$ & $\begin{array}{c}63.4 \\
(60.4-66.5)\end{array}$ & $\begin{array}{c}16.8 \\
(16.2-17.5)\end{array}$ & $\begin{array}{c}31 \\
(29-32)\end{array}$ & $\begin{array}{c}67 \\
(64-69)\end{array}$ \\
\hline 1996 & 179 & $\begin{array}{c}4.8 \\
(0.6-8.2)\end{array}$ & $\begin{array}{c}1.9 \\
(1.8-2.1)\end{array}$ & $\begin{array}{c}4.7 \\
(4.3-5.1)\end{array}$ & $\begin{array}{c}5.6 \\
(50-6.2)\end{array}$ & $\begin{array}{c}1574 \\
(1440-1715)\end{array}$ & $\begin{array}{c}14.3 \\
(13.0-15.7)\end{array}$ & $\begin{array}{c}72.9 \\
(69.9-75.9)\end{array}$ & $\begin{array}{c}19.5 \\
(18.7-20.3)\end{array}$ & $\begin{array}{c}37 \\
(36-38)\end{array}$ & $\begin{array}{c}42 \\
(40-45\}\end{array}$ \\
\hline All years & 385 & $\begin{array}{c}4.5 \\
(0.6-16.6)\end{array}$ & $\begin{array}{c}1.8 \\
(1.7-1.9)\end{array}$ & $\begin{array}{c}5.3 \\
(5.0-5.6)\end{array}$ & $\begin{array}{c}6.0 \\
(5.6-6.4)\end{array}$ & $\begin{array}{c}1808 \\
(1700-1918)\end{array}$ & $\begin{array}{c}12.7 \\
(11.8-i .3 .6)\end{array}$ & $\begin{array}{c}68.0 \\
(65.9-70.2)\end{array}$ & $\begin{array}{c}18.1 \\
(17.6-18.6)\end{array}$ & $\begin{array}{c}34 \\
(33-35)\end{array}$ & $\begin{array}{c}55 \\
(53-57)\end{array}$ \\
\hline \multicolumn{12}{|c|}{ Differences between medians/means } \\
\hline 1994 vs 1 & 995 & $\cdot$ & . & - & ns & - & ns & ns & ns & - & - \\
\hline 1994 vs 1 & 996 & . & - & - & ns & - & ns & ns & ns & ns & - \\
\hline 1995 vs 1 & 990 & - & ins & * & ns & - & • & • & - & - & - \\
\hline
\end{tabular}

\section{Differences in foraging behaviour between years}

Dive data were obtained for a total of 385 foraging trips totalling $1964 \mathrm{~d}$ at sea (Table 2). Trip durations were highly skewed to the right and therefore the median time spent at sea was calculated to be $4.5 \mathrm{~d}$ (range 0.6 to 16.6 , excluding 4 females in 1994 that abandoned their pups for $>20 \mathrm{~d}$ ). On average, females remained ashore for 1.8 d $195 \%$ confidence interval 1.7-1.9). Females began diving $5.3 \mathrm{~h}$ (5.0-5.6) after leaving the colony, and the time between last diving and returning ashore was $6.0 \mathrm{~h}(5.6-6.4)$. On average, females made 1808 (1700-1918) dives during each foraging trip, 55\% (53-57) of which were made at night. The median was used to describe dive depth and duration during each trip because distributions were skewed to the right. For all trips, the mean dive depth was $12.7 \mathrm{~m}$ (11.8-13.6) and dive duration was $68.0 \mathrm{~s}(65.9-70.2)$. Females were submerged for $34 \%(33-35)$ of the foraging period and had a dive frequency of 18.1 dives $h^{-1}(17.6-18.6)$.

Ashore duration was positively correlated with the preceding trip duration (Spearman Rank correlation $\mathrm{r}=$ 0.38 ), and outward travel time ( $\mathrm{r}=$ $0.28)$, return travel time $(r=0.18)$, number of dives ( $r=0.82$ ) and percentage of dives at night $(r=0.54)$ during each foraging trip were also correlated with foraging trip duration ( $p<0.001$ in all cases). Dive depth $(r=-0.42)$, dive duration $(r=-0.48)$ and percentage time submerged $(r=-0.42)$ were negatively correlated ( $\mathrm{p}<0.001$ in all cases); however, dive frequency was not correlated with trip duration ( $r=0.002, p=$ $0.96)$.

Foraging behaviour was significantly different between years (Kruskal-Wallis and ANOVA $\mathrm{p}<0.05$ ), with the exception of return time $(p=0.15)$ (Table 2$)$. In

Table 3. Results of a Student's t-test (pairwise comparison) to test the null hypothesis that the mean difference in foraging behaviour between years was not different from zero

\begin{tabular}{|c|c|c|c|c|c|c|}
\hline \multirow[t]{2}{*}{ Behaviour } & \multicolumn{2}{|c|}{1995 vs 1994} & \multicolumn{2}{|c|}{1996 vs 1994} & \multicolumn{2}{|c|}{1996 vs 1995} \\
\hline & $\begin{array}{l}\text { Mean } \\
\text { difference }\end{array}$ & $\mathrm{p}$ & $\begin{array}{l}\text { Mean } \\
\text { difference }\end{array}$ & $\mathrm{p}$ & $\begin{array}{l}\text { Mean } \\
\text { difference }\end{array}$ & $\mathrm{p}$ \\
\hline Trip duration (d) & -2.4 & 0.27 & -3.2 & 0.03 & -0.5 & 0.23 \\
\hline Ashore duration (d) & 0.19 & 0.70 & 0.39 & $0.47^{\mathrm{d}}$ & 0.36 & 0.21 \\
\hline Outward travel (h) & -7.3 & 0.11 & -8.3 & $0.0006^{\mathrm{a}}$ & -0.35 & 0.64 \\
\hline Return travel (h) & -2.2 & 0.54 & -3.7 & 0.44 & -1.8 & 0.04 \\
\hline Number of dives & -1683 & 0.17 & -2286 & 0.03 & -50.2 & 0.85 \\
\hline Dive depth $\{\mathrm{m})$ & 5.0 & 0.42 & 1.0 & 0.82 & 3.6 & 0.04 \\
\hline Dive duration (s) & 13.8 & 0.36 & 12.0 & 0.21 & 12.2 & 0.008 \\
\hline $\begin{array}{l}\text { Dive frequency } \\
\text { (dives } \mathrm{h}^{-1} \text { ) }\end{array}$ & -0.68 & 0.39 & -0.41 & 0.84 & 0.60 & $0.10^{\mathrm{a}}$ \\
\hline$\%$ time submerged & 0.77 & 0.84 & 1.7 & 0.72 & 3.6 & $0.02^{b}$ \\
\hline$\%$ dives at night & -1.7 & 0.80 & -18.3 & 0.007 & -23.5 & 0.0002 \\
\hline No. of individuals & 4 & & 5 & & $15^{c}$ & \\
\hline \multicolumn{7}{|c|}{ aData was normalised by calculating the percentage difference } \\
\hline \multicolumn{7}{|c|}{$\begin{array}{l}\text { Data could not be normalised and therefore a Wilcoxon rank sum test was } \\
\text { used to test the difference between medians }\end{array}$} \\
\hline \multicolumn{7}{|c|}{$\begin{array}{l}\text { 'Two females were excluded as dates of trips were different by }>15 \mathrm{~d} \\
\text { between years }\end{array}$} \\
\hline
\end{tabular}




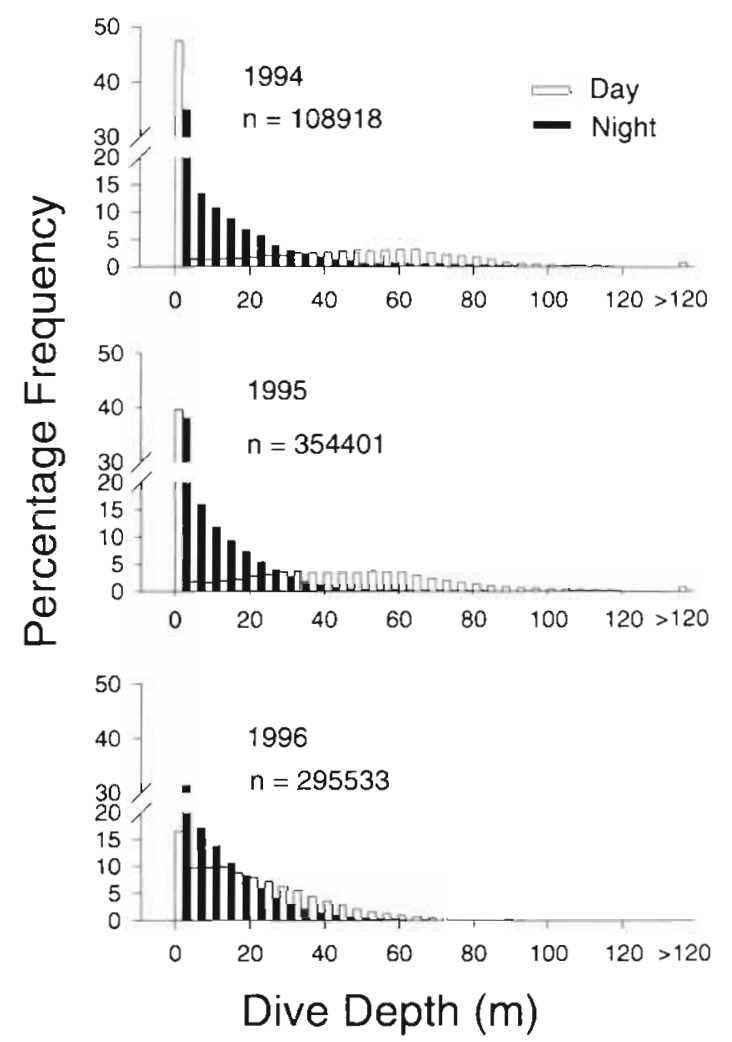

Fig. 1. Distribution of dive depths $(m)$ made by female Antarctic fur seals during breeding seasons, 1994 to 1996. Dives were divided into those made during the day (open bars) and those made at night (solid bars)

1994, foraging trips were $40 \%$ longer, outward travel time increased by $60 \%$, and females made twice as many dives during each trip and spent $25 \%$ less time ashore than in 1996. Dive depth and duration were marginally but significantly greater in 1996 than in 1995. Examination of dive depth and duration distributions indicated that this was due to the low frequency of shallow and short duration dives in 1996 (Fig. 1). However, in 1996 there was a small number of deep $(>50 \mathrm{~m})$ dives during the day. The percentage of time submerged differed by only 2 to $6 \%$ between years. During 1996, females made $30 \%$ less dives at night than in the previous 2 years and dive frequency was greater than in 1995.

No difference in the foraging behaviour of the same individuals was detected between 1995 and 1994 (paired $t$ test $p \geq 0.11$ in all cases; Table 3 ). However, individuals in 1996 were found to have made shorter foraging trips, spent less time on outward travel, made fewer dives and reduced the percentage of dives at night $(p \leq 0.03)$ compared to 1994. Compared with 1995, individuals in 1996 spent less time on return travel, made deeper and longer dives, spent more time submerged and had a lower percentage of dives at night $(\mathrm{p} \leq 0.04)$.

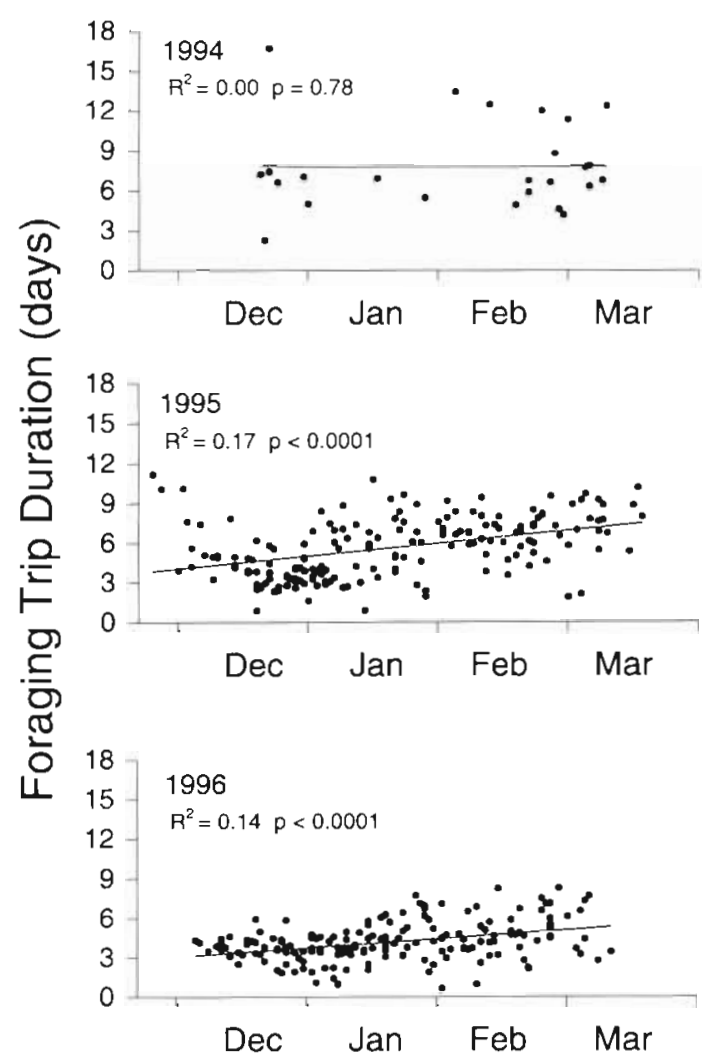

Fig. 2. Foraging trip duration (d) of female Antarctic fur seals during breeding seasons, 1994 to 1996 . The coefficient of determination $\left(\mathrm{R}^{2}\right)$ was calculated by linear regression and an $F$-test was used to test significance. The regression line is shown and significance of the gradient was tested using a Student's $t$-test (see Table 4)

\section{Differences in foraging behaviour within years}

Changes in foraging behaviour throughout the breeding season were examined by linear regression of foraging variables with start date of trip (Table 4). Overall, females increased foraging trip duration throughout 1995 and 1996, although there appeared to be a decrease in trip duration at the start of 1995 (Fig. 2). In 1994 no change in trip duration was found, but in all years females increased the time spent ashore throughout the season. There was no change in outward and return travel times in 1994 and 1995 and there was only a small increase in 1996.

In 1995 and 1996 females increased the number of dives per foraging trip, but in all years females also increased their dive frequency throughout the season. (Fig. 3). Overall, dive depth decreased throughout 1995 and 1996 and there was a corresponding decrease in dive duration (Table 4). Dive depth and duration (not shown) increased from the start of the season until late December and decreased during January (Fig. 4). In 1994 females increased time spent sub- 


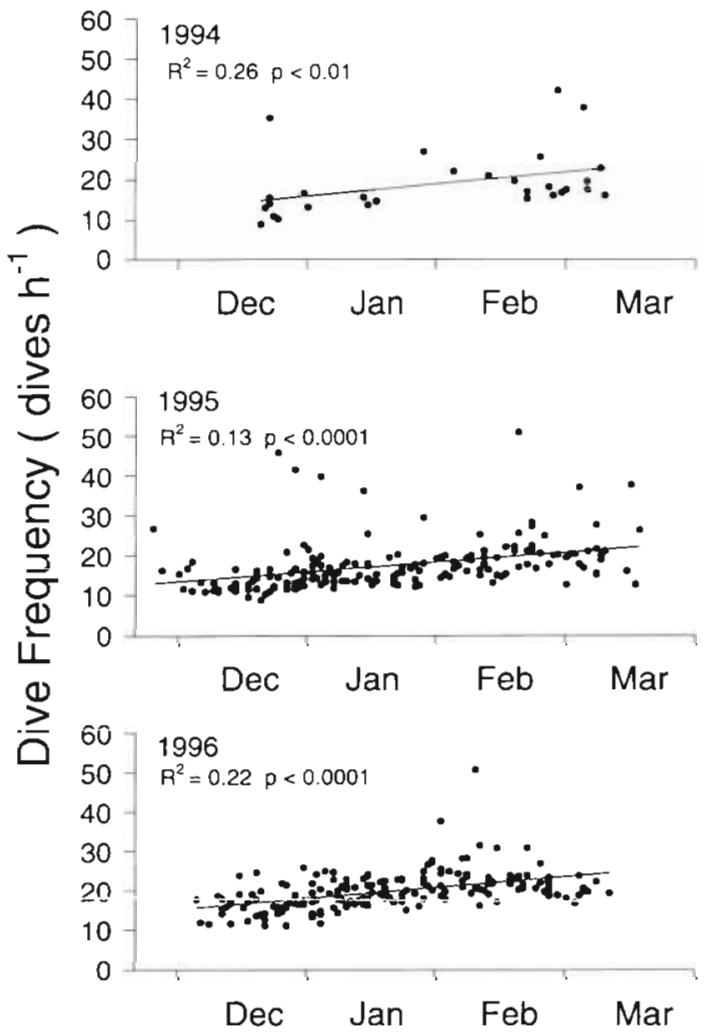

Fig. 3. Dive frequency (dives $\mathrm{h}^{-1}$ ) of female Antarctic fur seals during each foraging trip throughout the breeding seasons 1994 to 1996 . The coefficient of determination $\left(R^{2}\right)$ was calculated by linear regression and an $F$-test was used to test significance. The regression line is shown and significance of the gradient was tested using a Student's $t$-test (see Table 4)

merged during each foraging trip (Table 4). With the exception of a decrease at the start of the 1995 season, females increased the percentage of dives made at night during 1995 and 1996.

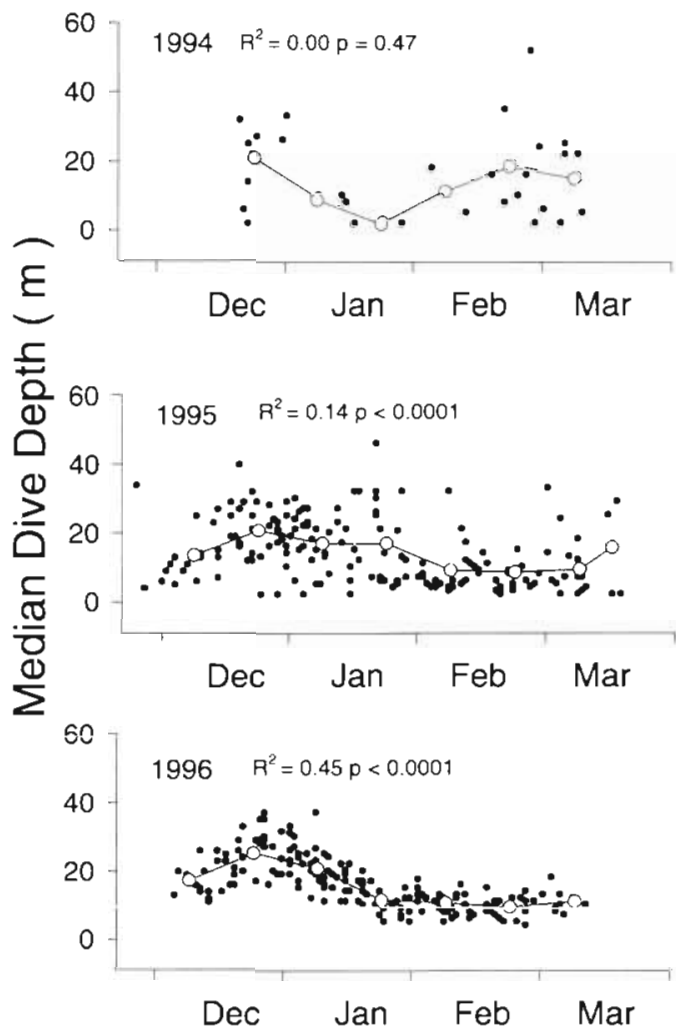

Fig 4. Median dive depth (m) of female Antarctic fur seals during each foraging trip throughout the breeding seasons 1994 to 1996 . The coefficient of determination $\left(R^{2}\right)$ was calculated by linear regression and an $F$-test was used to test significance. Median dive depths averaged over 2 wk intervals are also shown (large open symbols)

Mean monthly dive data were available for 12 individuals from 1995 and 1996 . To account for multiple sampling from the same individuals a repeated measures ANOVA was used to test for differences in forag-

Table 4. Linear regression coefficients $( \pm \mathrm{SE}$ ) of foraging parameters with start date of foraging trip (days since 1 December). An $F$-test was used to test the significance of the coefficient of determination ( $R^{2}, p<0.01$; ns: $p>0.05$ ) and a Student's $t$-test was used to determine if regression coefficients were significantly different from zero ( $\left.p<0.02 ;{ }^{n s} p>0.05\right)$

\begin{tabular}{|c|c|c|c|c|c|c|}
\hline & 1994 & $\mathrm{R}^{2}$ & 1995 & $\mathrm{R}^{2}$ & 1996 & $\mathrm{R}^{2}$ \\
\hline Trip duration (d) & $0.007 \pm 0.024^{\mathrm{ns}}$ & ns & $0.032 \pm 0.005$ & 0.17 & $0.023 \pm 0.004^{\circ}$ & 0.14 \\
\hline Ashore duration $(\mathrm{d})$ & $0.020 \pm 0.007^{\circ}$ & 0.38 & $0.013 \pm 0.003$ & 0.14 & $0.012 \pm 0.003^{\circ}$ & 0.07 \\
\hline Outward travel (h) & $-0.029 \pm 0.034^{\mathrm{ns}}$ & ns & $-0.019 \pm 0.012^{\mathrm{ns}}$ & ns & $0.034 \pm 0.014^{\circ}$ & 0.03 \\
\hline Return travel (h) & $-0.040 \pm 0.045^{\mathrm{ns}}$ & ns & $-0.011 \pm 0.015^{\mathrm{ns}}$ & ns & $0.030 \pm 0.010^{\circ}$ & 0.05 \\
\hline Number of dives & $14.5 \pm 11.1^{\mathrm{ms}}$ & ns & $25.4 \pm 2.7$ & 0.34 & $15.1 \pm 1.8^{\circ}$ & 0.28 \\
\hline Dive depth (m) & $-0.065 \pm 0.089^{\mathrm{ns}}$ & ns & $-0.123 \pm 0.023$ & 0.14 & $-0.210 \pm 0.017^{\circ}$ & 0.45 \\
\hline Dive duration (s) & $-0.104 \pm 0.1 .86^{\mathrm{ns}}$ & ns & $-0.361 \pm 0.057$ & 0.19 & $-0.470 \pm 0.034$ & 0.52 \\
\hline Dive frequency (dives $h^{-1}$ ) & $0.131 \pm 0.046^{\circ}$ & 0.26 & $0.080 \pm 0.016$ & 0.13 & $0.092 \pm 0.013^{\circ}$ & 0.22 \\
\hline$\%$ time submerged & $0.238 \pm 0.062^{\circ}$ & 0.39 & $0.018 \pm 0.024^{\mathrm{ns}}$ & ns & $-0.036 \pm 0.026^{\mathrm{ns}}$ & $\mathrm{ns}$ \\
\hline$\%$ dives at night & $0.092 \pm 0.104^{\mathrm{ns}}$ & ns & $0.256 \pm 0.036$ & 0.22 & $0.222 \pm 0.052^{\circ}$ & 0.09 \\
\hline
\end{tabular}


Table 5. Effect of year, instrument type and age class on foraging behaviour of female Antarctic fur seals (3-way ANOVA, see 'Materials and methods'). An F-test was used to determine the significance of each model and the variance explained was described by the coefficient of determination $\left(R^{2}\right)$. The significance of factors was determined from partial sums of squares using an $F$-test. $\cdots p<0.001, \cdots p<0.01, \cdot p<$ $0.05 ; \mathrm{ns}: \mathrm{p}>0.05$. $\mathrm{n}$ is the number of individuals

\begin{tabular}{|c|c|c|c|c|c|c|}
\hline Behaviour & Year & $\begin{array}{l}\text { Inst. } \\
\text { type }\end{array}$ & $\begin{array}{l}\text { Age } \\
\text { class }\end{array}$ & $\mathrm{R}^{2}$ & $\mathrm{n}$ & $\mathrm{p}$ \\
\hline Trip duration (d) & ... & ns & . & 0.47 & 55 & 0.0001 \\
\hline Ashore duration (d) & ns & ns & ns & 0.10 & 41 & 0.55 \\
\hline Outward travel (h) & ns & ns & ns & 0.19 & 55 & 0.06 \\
\hline Return travel (h) & $\mathrm{ns}$ & $\mathrm{ns}$ & ns & 0.14 & 51 & 0.21 \\
\hline Number of dives & .. & $\cdots$ & ns & 0.51 & 55 & 0.0001 \\
\hline Dive depth (m) & ns & .. & ns & 0.27 & 55 & 0.006 \\
\hline Dive duration (s) & - & $\cdots$ & ns & 0.33 & 55 & 0.001 \\
\hline $\begin{array}{l}\text { Dive frequency } \\
\text { (dives } \mathrm{h}^{-1} \text { ) }\end{array}$ & ns & $\cdots$ & - & 0.27 & 55 & 0.008 \\
\hline$\%$ time submerged & ns & ns & ns & 0.17 & 55 & 0.10 \\
\hline$\%$ dives at night & $\cdots$ & • & ns & 0.51 & 55 & 0.0001 \\
\hline
\end{tabular}

ing behaviour between months. Foraging behaviour was significantly different between months $(p<0.05$ all cases), with the exception of outward travel time (p $=0.94$ ) and ashore duration (insufficient sample size).

Táble 6 . Miean furaging parameters of female Antarctic fur seals $195 \%$ confidence interval) where age class or instrument type had a significant effect. Individual comparisons were made using a Student's t-test (significant at $" p<0.05$ )

\begin{tabular}{|c|c|c|c|c|c|c|}
\hline Age class & \multicolumn{3}{|c|}{$\leq 6 \mathrm{yr}$} & \multicolumn{3}{|c|}{$>6 \mathrm{yr}$} \\
\hline No. of seals & \multicolumn{3}{|c|}{14} & \multicolumn{3}{|c|}{41} \\
\hline Trip duration (d) & \multicolumn{3}{|c|}{$\begin{array}{c}5.2 \\
(3.8-6.6)\end{array}$} & \multicolumn{3}{|c|}{$\begin{array}{c}7.4 \\
(6.6-8.2)\end{array}$} \\
\hline $\begin{array}{l}\text { Dive frequency } \\
\text { (dives } \mathrm{h}^{-1} \text { ) }\end{array}$ & \multicolumn{3}{|c|}{$\begin{array}{c}23.0 \\
(19.5-26.5)\end{array}$} & \multicolumn{3}{|c|}{$\begin{array}{c}19.2 \\
(17.3-21.1)\end{array}$} \\
\hline Instrument type & $\mathrm{Mk} 3$ & Mk5 & Mk6 & $\begin{array}{c}\text { Mk3 } \\
\text { vs } \\
\text { MK5 }\end{array}$ & $\begin{array}{c}\text { Mk3 } \\
\text { vs } \\
\text { Mk6 }\end{array}$ & $\begin{array}{c}\text { Mk5 } \\
\text { vs } \\
\text { Mk6 }\end{array}$ \\
\hline No. of seals & 8 & 35 & 12 & & & \\
\hline No. of dives & $\begin{array}{c}3286 \\
(2459-4113)\end{array}$ & $\begin{array}{c}1954 \\
(1625-2283)\end{array}$ & $\begin{array}{c}2889 \\
(2217-3561\}\end{array}$ & - & ns & $\cdot$ \\
\hline Dive depth (m) & $\begin{array}{c}6.7 \\
(-1.3-14.7)\end{array}$ & $\begin{array}{c}18.7 \\
(15.4-22.0)\end{array}$ & $\begin{array}{c}15.9 \\
(9.3-22.5)\end{array}$ & . & - & ns \\
\hline Dive duration (s) & $\begin{array}{c}46.1 \\
(28.9-63.3)\end{array}$ & $\begin{array}{c}72.7 \\
(65.8-79.6)\end{array}$ & $\begin{array}{c}63.6 \\
(49.5-77.7)\end{array}$ & $\cdot$ & ns & ns \\
\hline $\begin{array}{l}\text { Dive frequency } \\
\text { (dives } \mathrm{h}^{-1} \text { ) }\end{array}$ & $\begin{array}{c}26.1 \\
(21.5-30.7)\end{array}$ & $\begin{array}{c}18.0 \\
(16.1-19.9)\end{array}$ & $\begin{array}{c}19.3 \\
(15.5-23.1)\end{array}$ & • & ns & . \\
\hline$\%$ dives at night & $\begin{array}{c}51.0 \\
(40.8-61.2)\end{array}$ & $\begin{array}{c}60.8 \\
(56.7-64.9)\end{array}$ & $\begin{array}{c}53.6 \\
(45.2-62.0)\end{array}$ & $\cdot$ & ns & ns \\
\hline
\end{tabular}

\section{Effect of instrument and maternal characteristics on foraging behaviour}

Females were distinguished on the basis of age class, as older females had a greater body mass and body length ( 2 -way ANOVA $p<0.03$ in both cases), and in this sample there was no difference between year ( $p>$ $0.05)$ and no interaction with year $(p>0.18)$. There was also no effect of age class or year on body condition $(p>0.05)$.

Year, instrument type and age class explained 27 to $47 \%$ of the variation in foraging trip duration, number of dives, dive depth and duration, dive frequency and percentage of dives at night (Table 5). Trip duration varied significantly with age class and year. The number of dives, dive duration and percentage of dives at night varied significantly with instrument type and year, while dive depth was only significantly different between instrument type (Table 5). Models of ashore duration, outward travel and return travel were non significant $(\mathrm{p}>0.05)$.

Individual comparisons showed that younger females made shorter foraging trips (Student's $t$-test $p<0.02$ ) and had higher dive frequencies ( $p<0.003)$ (Table 6). On average, deployments with $\mathrm{Mk} 3$ and Mk6 devices recorded a greater number of dives than deployments with Mk5s ( $\mathrm{p}<0.001$ ). Dive depth and duration recorded by Mk3s was on average less than for dives recorded by $\mathrm{Mk} 5 \mathrm{~s}$ ( $\mathrm{p}<0.002$ ). Deployments made with Mk3 TDRs recorded a greater dive frequency than Mk5 and Mk6 TDRs ( $p<0.01$ ), and $\mathrm{Mk} 3 \mathrm{~s}$ also recorded a lower percentage of dives at night than deployments with Mk5s ( $<<0.04)$.

Trip durations decreased between 1994 and 1996 ( $\mathrm{p}<0.01$ ) and there was a greater number of dives in 1994 than in 1995 and 1996 ( $\mathrm{p}<0.001$; Table 6). In 1995 dives were shorter than in 1996 ( $\mathrm{p}<0.04)$ and percentage of dives at night was less in 1996 than in the previous 2 years $(p<0.001)$.

\section{Pup growth, environmental variation and diet}

\section{Pup growth}

In 1994, when there was a high rate of pup mortality in the colony, 10 of the study pups died compared with 4 in 1995 and only 1 in 1996. A 2-way 
Table 7 . Mean ( $\pm 95 \%$ confidence interval, no. of pups) body size of Antarctic fur seal pups during the perinatal perlod, overall growth rate and body size at weaning. A 2-way ANOVA was used to test for differences between sex and year (see 'Results'). Individual comparisons between means were significantly different $(\cdot)$ at $p<0.05$ (Student's $t$-test; ns: not significant). Body length was not measured in 1994

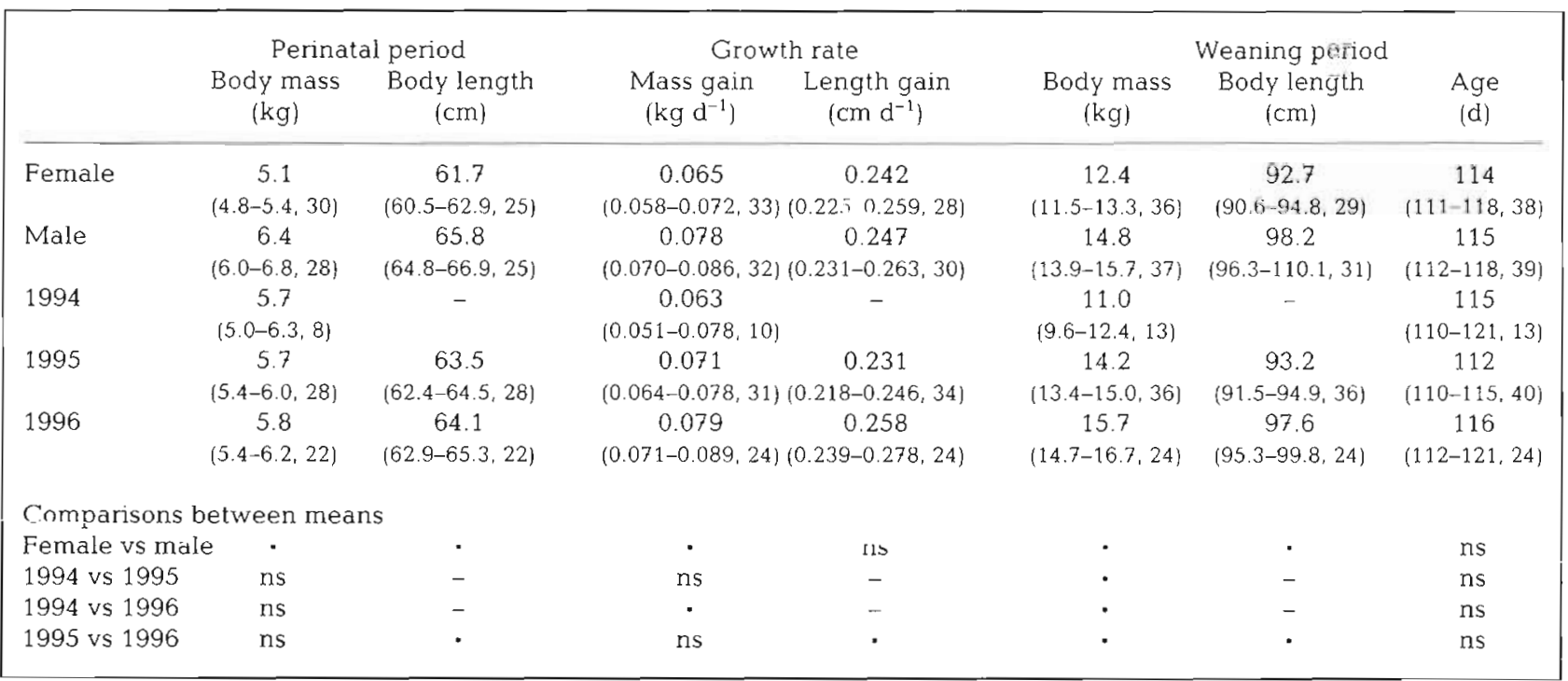

ANOVA was used to examine differences in growth of surviving pups between years and between sexes (Table 7). In all cases there was no interaction between sex and year $(p>0.09)$. There was no difference in perinatal body size (mass and length) between years ( $p<0.0001$ both cases); however, male pups had a larger body size than female pups ( $p>0.43$ ). There was a difference in the rate of mass and length gain between years ( $p<0.05$ ). In 1996 mass gain was on average $25 \%$ greater than in 1994 and length gain was $12 \%$ greater than in 1995 (Table 7). Male pups had a greater rate of mass gain than females ( $p<0.002)$ but no difference in length gain was detected ( $p=0.60)$. Body size (mass and length) at weaning was different between years $(p<0.01)$. Pup body size was greatest in 1996 than in previous years, and in all years, male pups were larger than females at weaning (Table 7). There was no difference in weaning age between years or between sexes $(p>0.18)$.

\section{Environmental variation}

There was significant variation in SST around South Georgia (taken from ship, buoy and satellite data) between months ( 2 -way ANOVA $p<0.0001$ ). On average SST increased from $1.7^{\circ} \mathrm{C}$ in December to $3.9-$ $4.0^{\circ} \mathrm{C}$ in February and March (Table 8 ). There was no difference in SST between years $(p=0.82)$. Although there was a significant interaction between month and year $(\mathrm{p}<0.0001)$, there was no obvious trend in mean monthly SST across years (Table 8 ).
Satellite tracking of fur seals at Bird Island in 1995 and 1996 showed that most locations were obtained from an area centred around $53.67^{\circ} \mathrm{S}, 39.0^{\circ} \mathrm{W}$ (Boyd et al. in press). There was good agreement between SST derived from satellite based measurements in this region and SST measured by TDRs (Fig. 5). An exception to this was in January 1994, when data was available from only 2 females that abandoned their pups for $>20$ d. SST from TDRs varied between months (2-way ANOVA $p<0.0001)$. On average SST increased from $1.9^{\circ} \mathrm{C}$ in December to $3.8-3.9^{\circ} \mathrm{C}$ in February and

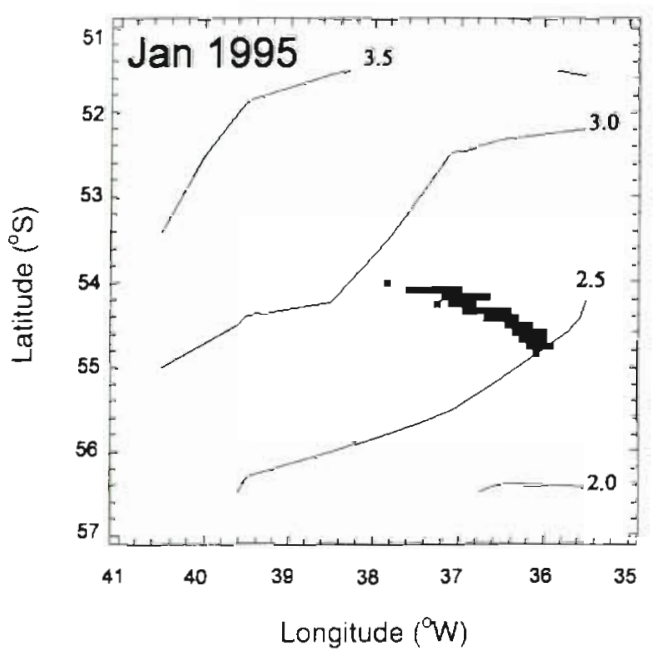

Fig. 5. Mean monthly SST isotherms $\left({ }^{\circ} \mathrm{C}\right)$ for South Georgia in January 1995. Data were obtained from ship, buoy and biascorrected satellite data from the Integrated Global Ocean Services System (IGOSS) 
Table 8. Mean ( $\pm 95 \%$ confidence interval, no. of data points/no. of trips) sea surface temperature (SST) around South Georgia during breeding seasons, 1994 to 1996. Mean monthly SST from ship, buoy and bias-corrected satellite data for South Georgia (see 'Materials and methods') and mean monthly SST recorded by TDRs during fur seal foraging trips are shown. A 2-way ANOVA was used to test for differences between months and years (see 'Results') and individual comparisons were made using a Student's $t$-test [significant $(\cdot)$ at $p<0.05$; ns: not significant.]. Note that Dec refers to December in previous calendar year

\begin{tabular}{|c|c|c|c|c|c|c|c|}
\hline & 1994 & 1995 & 1996 & All years & 1994 vs 1995 & $\begin{array}{c}\text { Comparison } \\
1994 \text { vs } 1996\end{array}$ & 1995 vs 1996 \\
\hline \multicolumn{8}{|c|}{ Ship, buoy and satellite data } \\
\hline Dec & $\begin{array}{c}2.0 \\
(1.7-2.2 .36)\end{array}$ & $\begin{array}{c}1.9 \\
(1.8-2.0,36)\end{array}$ & $\begin{array}{c}1.4 \\
(1.2-1.6,36)\end{array}$ & $\begin{array}{c}1.7 \\
(1.6-1.9 .108)\end{array}$ & ns & $\cdot$ & $\cdot$ \\
\hline $\operatorname{Jan}$ & $\begin{array}{c}3.3 \\
(3.1-3.5,36)\end{array}$ & $\begin{array}{c}2.9 \\
(2.8-3.1,36)\end{array}$ & $\begin{array}{c}3.1 \\
(2.8-3.3,36)\end{array}$ & $\begin{array}{c}3.0 \\
(3.1-3.2,108)\end{array}$ & • & ns & ns \\
\hline Feb & $\begin{array}{c}4.0 \\
(3.8-4.2,36)\end{array}$ & $\begin{array}{c}4.0 \\
(3.8-4.2,36)\end{array}$ & $\begin{array}{c}4.0 \\
(3.7-4.2,36)\end{array}$ & $\begin{array}{c}4.0 \\
(3.9-4.1,108)\end{array}$ & ns & ns & ns \\
\hline Mar & $\begin{array}{c}3.4 \\
(3.2-3.6,36)\end{array}$ & $\begin{array}{c}4.1 \\
(3.8-4.3,36)\end{array}$ & $\begin{array}{c}4.4 \\
(4.1-4.6,36)\end{array}$ & $\begin{array}{c}3.9 \\
(3.8-4.1,108)\end{array}$ & • & * & ns \\
\hline \multicolumn{8}{|c|}{ TDR data } \\
\hline Dec & $\begin{array}{c}2.4 \\
(2.1-2.6,7)\end{array}$ & $\begin{array}{c}1.9 \\
(1.8-2.0,42)\end{array}$ & $\begin{array}{c}1.8 \\
(1.7-2.0,44\}\end{array}$ & $\begin{array}{c}1.9 \\
(1.8-2.0 .93)\end{array}$ & $\cdot$ & $\cdot$ & ns \\
\hline Jan & $\begin{array}{c}4.8 \\
(4.0-5.6,2)\end{array}$ & $\begin{array}{c}2.8 \\
(2.6-3.0,44)\end{array}$ & $\begin{array}{c}3.0 \\
(2.8-3.1,69)\end{array}$ & $\begin{array}{c}2.9 \\
(2.8-3.0,115)\end{array}$ & $\cdot$ & $\cdot$ & ns \\
\hline Feb & $\begin{array}{c}4.3 \\
(4.0-4.6,7)\end{array}$ & $\begin{array}{c}3.7 \\
(3.6-3.9 .29)\end{array}$ & $\begin{array}{c}3.7 \\
(3.6-3.9,45)\end{array}$ & $\begin{array}{c}3.8 \\
(3.7-3.9,81)\end{array}$ & $\cdot$ & $\cdot$ & ns \\
\hline Mar & $\begin{array}{c}4.4 \\
(4.0-4.6,4)\end{array}$ & $\begin{array}{c}3.9 \\
(3.7-4.0,16]\end{array}$ & $\begin{array}{c}3.6 \\
(3.4-3.9,6)\end{array}$ & $\begin{array}{c}3.9 \\
(3.7-4.1,26)\end{array}$ & $\cdot$ & $\cdot$ & ns \\
\hline
\end{tabular}

March (Table 8 ). There was a significant difference in mean monthly SST between years $(\mathrm{p}<0.0001)$ and an interaction between month and year $(\mathrm{p}<0.002)$. The mean SST recorded by TDRs in 1994 was greater than the subsequent 2 years (Table 8 ).

\section{Diet}

Overall, krill occurred in $89 \%$ of scats $(n=436), 47 \%$ of scats contained fish, and $7 \%$ of scats contained squid (Table 9). Although krill was the predominant prey item in all years, there was a difference in the proportion of scats containing krill between years (Chisquared test $p<0.0001$ ). In $1994,75 \%$ of scats con-

Table 9. Number of Antarctic fur seal scats containing krill, fish and squid during the breeding seasons, 1994 to 1996. A Chi-squared test showed that there was a difference between years in the proportion of scats containing krill $(p<0.0001)$, fish $(p<0.0001)$ and squid $(p<0.03)$. The percentage occurrence of each item is given in parentheses. $n$ is the number of scats

\begin{tabular}{|lcrrr|}
\hline \multirow{2}{*}{ Year } & $\mathrm{n}$ & \multicolumn{4}{c}{ Number of scats containing } \\
& & Krill & Fish & Squid \\
\hline 1994 & 150 & $113(75)$ & $101(67)$ & $15(10)$ \\
1995 & 146 & $139(95)$ & $64(44)$ & $12(8)$ \\
1996 & 140 & $137(98)$ & $39(28)$ & $3(2)$ \\
All years & 436 & $389(89)$ & $204(47)$ & $30(7)$ \\
\hline
\end{tabular}

tained krill compared to 95 and $98 \%$ in 1995 and 1996 (Table 9). The difference was due to a reduction in the percentage of scats containing krill in the middle and late stages of the 1994 season, this change did not occur in subsequent years. There was also a difference in the distribution of krill size between years (Kolmogorov-Smirnoff 2 -sample test $p<0.0001$ ). In 1994 small krill and large krill were relatively more frequent due to a seasonal shift from large krill (weekly median 50 to $60 \mathrm{~mm}$ ) early in the season to small krill (median 35 to $40 \mathrm{~mm}$ ) later on. In contrast, krill length remained relatively constant during 1995 and 1996 (median 35 to $45 \mathrm{~mm}$ ) (Fig. 6).

There was a difference in the proportion of scats containing fish between years (Chi-squared test $\mathrm{p}<$ 0.0001 ) and the percentage of scats containing fish

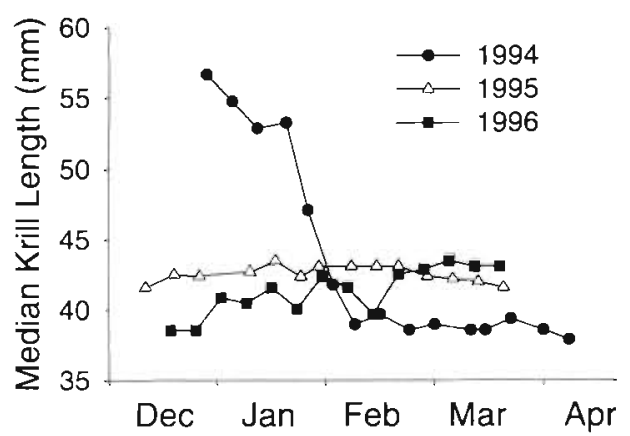

Fig. 6. Median krill length (mm) taken by female Antarctic fur seals during breeding seasons, 1994 to 1996 
decreased from $67 \%$ in 1994 to $28 \%$ in 1996 (Table 9). In 1994 the percentage of fish increased when krill was less common, and there were greater percentages of fish at the end of the 1995 and the beginning of the 1996 seasons. Although squid was an uncommon prey item, there was a difference in the proportion of scats containing squid between years $(\mathrm{p}<0.03)$ and the proportion decreased from 10 to $2 \%$ between 1994 and 1996 (Table 9). Squid occurred more frequently in the middle of the 1994 season, when the percentage of krill decreased and fish also became more frequent.

\section{Variation in foraging behaviour between and within years}

Variation in foraging behaviour between and within years was examined using multiple regression (Table 10a). Female identity and year accounted for 77

Table 10. Multiple linear regression of foraging parameters with sea surface temperature (SST), duration of night, pup age and pup mass as explanatory variables and female identity, year, instrument type and female age class as factors. (a) Results of full models that contain all explanatory variables. (b) All possible regression models for foraging trip duration (·variable/factor not included in model). An F-test was used to determine the significance of each model and the variance explained was described by the coefficient of determination $\left(\mathrm{R}^{2}\right)$. The significance of factors and variables was determined from partial sums of squares using an F-test $(\cdots p<0.001, \cdots p<0.01, " p<0.05 ; n s: p>0.05)$ and + or - indicates the sign of the regression coefficient $(3$ symbols: $p<0.001$ : 2 symbols: $p<0.01 ; 1$ symbol: $p<0.05 ;$ ns: $p>0.05$ )

\begin{tabular}{|c|c|c|c|c|c|c|c|c|c|c|c|c|}
\hline \multicolumn{2}{|c|}{ (a) Full models } & $\begin{array}{l}\text { Female } \\
\text { identity }\end{array}$ & Year & $\begin{array}{l}\text { Instru- } \\
\text { ment } \\
\text { type }\end{array}$ & $\begin{array}{c}\text { Female } \\
\text { age } \\
\text { ciass }\end{array}$ & $\begin{array}{l}\text { SST } \\
\left({ }^{\circ} \mathrm{C}\right)\end{array}$ & $\begin{array}{l}\text { Night } \\
\text { duration } \\
\text { (hi) }\end{array}$ & $\begin{array}{l}\text { Pup } \\
\text { age } \\
\text { (d) }\end{array}$ & $\begin{array}{l}\text { Pup } \\
\text { mass } \\
\{\mathrm{kg}\}\end{array}$ & $\mathrm{R}^{2}$ & $\mathrm{n}$ & $\mathrm{p}$ \\
\hline \multicolumn{2}{|c|}{ Trip duration (d) } & $\cdots$ & $\cdots$ & $\cdot$ & ns & +++ & ++ & ns & -- & 0.89 & 291 & 0.0001 \\
\hline \multicolumn{2}{|c|}{ Ashore duration (d) } & $\cdots$ & $\cdots$ & ns & ns & $\mathrm{ns}$ & ns & ns & ns & 0.51 & 261 & 0.0001 \\
\hline \multicolumn{2}{|c|}{ Outward travel (h) } & ns & ns & ns & ns & ns & +++ & ns & ns & 0.21 & 291 & 0.0635 \\
\hline \multicolumn{2}{|c|}{ Return travel (h) } & ns & ns & ns & ns & ns & ns & ns & $\mathrm{ns}$ & 0.20 & 263 & 0.1072 \\
\hline \multicolumn{2}{|c|}{ Number of dives } & $\cdots$ & $\cdots$ & ns & ns & +++ & ns & $\mathrm{ns}$ & - & 0.65 & 291 & 0.0001 \\
\hline \multicolumn{2}{|c|}{ Dive depth (m) } & $\cdots$ & ns & ns & ns & --- & -- & ++ & ns & 0.54 & 291 & 0.0001 \\
\hline \multicolumn{2}{|c|}{ Dive duration (s) } & $\cdots$ & $\cdot$ & ns & ns & --- & - & ns & ns & 0.59 & 291 & 0.0001 \\
\hline \multicolumn{2}{|c|}{ Dive frequency (dives $h^{-1}$ ) } & $\cdots$ & $\cdots$ & $\cdots$ & ns & ns & ns & ++ & ns & 0.49 & 291 & 0.0001 \\
\hline \multicolumn{2}{|c|}{$\%$ time submerged } & $\cdots$ & $\cdots$ & $\cdot$ & $\cdot$ & --- & --- & +++ & ns & 0.53 & 291 & 0.0001 \\
\hline \multicolumn{2}{|c|}{$\%$ dives at night } & $\cdots$ & $\cdots$ & $\cdots$ & ns & +++ & +++ & -- & ns & 0.72 & 291 & 0.0001 \\
\hline \multicolumn{13}{|c|}{ (b) Possible models for foraging trip duration } \\
\hline \multicolumn{2}{|c|}{ Factors Variables } & $\begin{array}{l}\text { Female } \\
\text { identity }\end{array}$ & Year & $\begin{array}{c}\text { Instru- } \\
\text { ment } \\
\text { type }\end{array}$ & $\begin{array}{c}\text { Female } \\
\text { age } \\
\text { class }\end{array}$ & $\begin{array}{l}\text { SST } \\
\left({ }^{\circ} \mathrm{C}\right)\end{array}$ & $\begin{array}{c}\text { Night } \\
\text { duration } \\
\text { (h) }\end{array}$ & $\begin{array}{l}\text { Pup } \\
\text { age } \\
\text { (d) }\end{array}$ & $\begin{array}{l}\text { Pup } \\
\text { mass } \\
(\mathrm{kg})\end{array}$ & $\mathrm{R}^{2}$ & n & $\mathrm{p}$ \\
\hline 1 & 0 & $\cdots$ & $\cdot$ & . & . & & & . & . & 0.77 & 291. & 0.0001 \\
\hline 1 & 0 & $\cdot$ & $\cdots$ & $\cdot$ & . & . & . & . & $\cdot$ & 0.22 & 291 & 0.0001 \\
\hline 1 & 0 & $\cdot$ & $\cdot$ & ns & $\cdot$ & . & . & . & $\cdot$ & 0.00 & 291 & 0.7153 \\
\hline 1 & 0 & $\cdot$ & $\cdot$ & $\cdot$ & ns & & . & · & $\cdot$ & 0.00 & 291 & 0.1610 \\
\hline 4 & 0 & $\cdots$ & $\cdots$ & ns & ns & · & & & . & 0.82 & 291 & 0.0001 \\
\hline 4 & 1 & $\cdots$ & $\cdots$ & ns & ns & +++ & · & & $\cdot$ & 0.88 & 291 & 0.0001 \\
\hline 4 & 1 & $\cdots$ & $\cdots$ & ns & ns & $\cdot$ & +++ & & . & 0.86 & 291 & 0.0001 \\
\hline 4 & 1 & $\cdots$ & $\cdots$ & ns & ns & $\cdot$ & & +++ & $\cdot$ & 0.86 & 291 & 0.0001 \\
\hline 4 & 1 & $\cdots$ & $\cdots$ & ns & ns & $\cdot$ & $\cdot$ & · & +++ & 0.85 & 291 & 0.0001 \\
\hline 4 & 2 & $\cdots$ & $\cdots$ & $\mathrm{ns}$ & ns & +++ & ns & . & $\cdot$ & 0.88 & 291 & 0.0001 \\
\hline 4 & 2 & $\cdots$ & $\cdots$ & $\cdot$ & ns & +++ & & $\cdot$ & - & 0.88 & 291 & 0.0001 \\
\hline 4 & 2 & $\cdots$ & $\cdots$ & ns & ns & +++ & & $\mathrm{ns}$ & & 0.88 & 291 & 0.0001 \\
\hline 4 & 2 & $\cdots$ & $\cdots$ & ns & ns & $\cdot$ & & +++ & -- & 0.87 & 291 & 0.0001 \\
\hline 4 & 2 & $\cdots$ & $\cdots$ & ns & ns & . & ns & + & $\cdot$ & 0.86 & 291 & 0.0001 \\
\hline 4 & 2 & $\cdots$ & $\cdots$ & ns & ns & $\cdot$ & +++ & $\cdot$ & ns & 0.86 & 291 & 0.0001 \\
\hline 4 & 3 & $\cdots$ & .. & $\cdot$ & ns & +++ & +++ & . & --- & 0.89 & 291 & 0.0001 \\
\hline 4 & 3 & $\ldots$ & $\cdots$ & $\cdot$ & ns & +++ & + & - & $\cdot$ & 0.88 & 291 & 0.0001 \\
\hline 4 & 3 & $\cdots$ & $\cdots$ & $\cdot$ & ns & +++ & $\cdot$ & ++ & --- & 0.88 & 291 & 0.0001 \\
\hline 4 & 3 & $\cdots$ & $\cdots$ & ns & ns & $\cdot$ & ns & +++ & -- & 0.87 & 291 & 0.0001 \\
\hline 4 & 4 & $\cdots$ & $\cdots$ & $\cdot$ & ns & +++ & ++ & $\mathrm{ns}$ & --- & 0.89 & 291 & 0.0001 \\
\hline
\end{tabular}


and $22 \%$ of the variation in foraging trip duration, respectively (Table $10 \mathrm{~b}$ ). Female age class and instrument type on their own did not explain any of the variation in trip duration but, when SST and pup mass were included, instrument type became significant (Table 10b). Female identity was a highly significant factor in foraging models (excluding outward and return travel time), and year also explained a significant amount of the variation in models (excluding travel time and dive depth) (Table 10a). Instrument type was significant in full models of trip duration, dive frequency, percentage submerged and percentage dives at night. In comparison, age class was only significant in the model of percentage time submerged (Table 10a)

SST was an important explanatory variable in models of trip duration, number of dives per foraging trip, dive depth and duration and percentage of dives at night. The regression coefficient for SST was significant when included individually or in combination with other explanatory variables (e.g. Table 10b). The sign of the regression coefficient indicated that trip duration, number of dives and percentage of dives increased with increasing SST but percentage time submerged, dive depth and duration decreased with increasing SST.

In models of ashore duration, the effect of adding explanatory variables was to increase the significance of year (Táble 10a). In particular, by including duration of night and SST, year became highly significant. None of the variables explained any of the variation in travel time. In contrast, pup age was the best predictor of dive frequency as the regression coefficient was significant in all models. The regression coefficient was positive, indicating that dive frequency increased with age of the pup. Pup age, duration of night and SST appeared to be equally good at explaining percentage time submerged (Table 10a). However, the regression coefficients showed that percentage time submerged increased with increasing pup age but decreased with increasing duration of night and increasing SST.

\section{DISCUSSION}

This study examined the foraging behaviour of fur seals during 3 years of contrasting prey abundance and breeding success. 1994 and 1996 were years of low and high krill abundance, respectively (Brierley \& Watkins 1996, Brierley et al. 1997), and in 1995 the diet of fur seals suggested that krill abundance was intermediate between the two. The foraging behaviour of females and growth rate of pups reflected these annual differences in prey abundance. How- ever, foraging behaviour also showed systematic changes within years. This provided an opportunity to examine how changes in prey abundance, environmental conditions and demands from offspring influenced foraging.

\section{Differences in foraging behaviour between years}

\section{Foraging trips}

Female fur seals made longer foraging trips in 1994 than in the subsequent 2 years. Foraging trips at Bird Island were also outstandingly long in 1984 and 1991 ( 6.8 and $8.4 \mathrm{~d}$, respectively) and in the remaining years between 1981 and 1993 trips ranged from 3.1 to $5.1 \mathrm{~d}$ (Croxall et al. 1988, Lunn et al. 1994). The consequence of long foraging trips during lactation is that although females may eventually be able to gain sufficient reserves for milk production, their absence may exceed the fast duration of pups or milk supplied may be only sufficient to make up for mass loss during the fast. This was observed in 1994 when pup mortality was the highest ever recorded and pup growth and weaning mass were amongst the lowest recorded on Bird Island in 16 yr (Lunn et al. 1993, Boyd et al. 1995). For a range of Otariids, similar reductions in pup growth and survival due to changes in maternal foraging behaviour have been observed during severe El Niño events (see review by Trillmich et al. 1991).

Krill was the predominant prey item in the diet in each year of the study. However, in 1994 a lower proportion of scats contained krill, and ship-based hydroacoustic surveys recorded extremely low krill densities around Bird Island (Brierley \& Watkins 1996). In comparison, krill densities in the same area during 1996 were 20 times greater (Brierley et al. 1997). Longer trip durations implied that females travelled further to find krill swarms and/or spent longer foraging for krill once swarms had been located. Satellite tracking has shown that females with longer trip durations travel greater distances from Bird Island, which would mean that the foraging range of females was on average $50 \%$ greater in 1994 than 1996 (Boyd unpubl.).

Although females made a greater number of dives on longer foraging trips in 1994 compared with 1996 , there was no difference in dive frequency or percentage of time submerged. This apparent lack of sensitivity in these variables supports the observation that Antarctic fur seals do not increase their metabolic rate in years of low krill abundance (Costa et al. 1989). Both these findings imply that when food was scarce, females simply spent longer searching for food to meet their own energy requirements and gain sufficient reserves for milk production. 
Timing of diving

In most years Antarctic fur seals have made the majority of their dives at night (Croxall et al. 1985, Boyd et al. 1991, 1994). However in 1996 and in 1992 (Boyd et al. 1994) females made 50 to $60 \%$ of their dives during the day. On a ship-based survey in 1996. large krill swarms were seen at the surface during the day (J. L. Watkins pers. comm.), and on occasion hydro-acoustic measurements at South Georgia have recorded the apparent migration of krill towards the surface during the middle of the day (Everson 1983) In addition, there is evidence to suggest that in years of high krill abundance, when food for krill is scarce krill do not migrate as far from the surface (Godlewska 1996). Fur seals may therefore have modified the timing of diving to match the period of greatest krill availability.

In 1996 females rarely dived to more than $50 \mathrm{~m}$, but in 1994 and 1995 females frequently dived to depths between 50 and $100 \mathrm{~m}$. This provided further evidence that krill were closer to the surface during the day in 1996. However, the high proportion of fish and squid in the diet in 1994 and 1995 may also suggest that deep daytime diving represented foraging for fish and squid.

\section{Differences in foraging behaviour within years}

\section{Foraging trips}

Increases in foraging trip duration throughout lactation have previously been shown to occur in several species of fur seals, including Antarctic fur seals (David \& Rand 1986, Doidge et al. 1986, Gentry \& Holt 1986, Trillmich 1986, Goldsworthy 1995). The progressive increase in trip duration throughout the 1995 and 1996 seasons suggested that females either were travelling further from Bird Island to feed, had lower foraging efficiencies or alternatively were increasing total foraging effort by making more dives. It was not known if females were foraging in different locations at different periods of the season. In 1995 there was no change in outward travel time, and in 1996 there was a poor relationship between travel time and date of trip. There may have been a seasonal decrease in foraging efficiency because of localised prey depletion or changes in prey abundance. However, it has been shown that females with long foraging trips also deliver greater amounts of milk energy to their pups (Arnould \& Boyd 1995b). Furthermore, there was a seasonal increase in attendance ashore (in contrast to a decrease reported by Goldsworthy 1995), which suggested that females had more milk to deliver later in the season (Arnould et al. 1996). It appeared that, when food supply was not limiting, females were able to increase their dive frequency and remain at sea longer so as to increase total energy intake throughout the season.

\section{Dive depth}

In 1995 and 1996 dive depth and dive duration increased from the start of the season until the end of December and decreased thereafter. Previously, Antarctic fur seals were found to make shallower and shorter dives later in the season (Boyd \& Croxall 1992). There is evidence to suggest that krill migrate progressively further from the surface between spring and mid-summer and then reduce their vertical migration towards the autumn (Godlewska 1996). Hence the observed change in dive depth would have matched the seasonal change in vertical migratory behaviour of krill. The greatest median dive depth in this study and the greatest migratory behaviour of krill corresponded to the lungest period of daylight. This may imply that fur seals were reacting to a photoperiodic response of krill or that foraging efficiency was greater at lower light levels because the prey escape response was reduced.

\section{Causes of variation in foraging behaviour}

Female identity, instrument type, age class, year, environmental factors and pup development were found to account for 49 to $89 \%$ of the variation in a range of foraging parameters. Female identity on its own explained almost $80 \%$ the variation in foraging trip duration and was also highly significant for all dive parameters. It was not surprising that individual differences explained a substantial proportion of the variation, as a wide range of animals of varying age, body size and reproductive experience were sampled. This study was unable to detect a strong effect of instrument type on foraging trip duration (instrument type was only just significant in the multiple regression model Table 10a). In contrast, Antarctic fur seals carrying TDR Mk3s were shown to increase their foraging trips by $15 \%$ compared to animals fitted with radiotransmitters (Walker \& Boveng 1995). Boyd et al. (1997) also demonstrated that females carrying packages equivalent in size to satellite transmitters remained at sea on average $30 \%$ longer than controls. Despite the small sample size and hence low statistical power of detecting a difference (Walker \& Boveng 1995), this study found that females with Mk3s made shorter and shallower dives than females carrying smaller and 
more streamlined Mk5 and Mk6s. Females with Mk3s also made a greater number of dives and had a higher dive frequency. The larger cross sectional profile of the instrument was probably subject to greater dynamic effects when animals travelled at the surface. This would account for a large number of short 1 to $3 \mathrm{~m}$ dives which were recorded by Mk3 TDRs during periods when no deep diving occurred during the day. However, extra drag has been shown to reduce swim speed and increase the proportion of short and shallow dives that fur seals make (Boyd et al. 1997), and in this study females may have compensated for this by increasing their dive frequency.

In this study, younger females made shorter foraging trips than older larger individuals. Boyd et al. (1991) found little evidence that age or body size influenced foraging cycle characteristics of Antarctic fur seals at Bird Island. However, recent studies at Seal Island, South Shetlands, indicated that larger females made shorter foraging trips (Walker \& Boveng 1995). Older and larger female Northern fur seals Callorhinus ursinus that gave birth earlier in the season also tended to make shorter foraging trips (Gentry et al. 1986, Goebel 1988). Of 55 individuals aged in this study, only 14 were aged 6 yr or less. Although the pregnancy rate is lower in this age group (Lunn et al. 1994), from the age distribution of females with pups on the beach it would have been expected that roughly half of the females caughit wuitud be ayed 3 to 6 (Boyd et al. 1995). Overall, sampling was biased with respect to age, and therefore effects of age were either unreliable or indistinguishable because of insufficient sample sizes of younger individuals. Sampling was probably biased towards young individuals in 1994 because of the later sampling time (Boyd \& McCann 1989, Boyd et al. 1990), and the overall bias towards older individuals may have occurred because a greater proportion of larger and 'healthier' looking individuals may have been selected for instrument deployment.

Even accounting for instrument effects and maternal characteristics, there remained significant differences in foraging behaviour across years. Physiological constraints that limit the aerobic capacity of diving would explain why dive duration and dive depth did not vary much across years. However, parameters that may reflect differences in foraging effort, such as trip duration, number of dives, dive frequency and percentage of time submerged showed greater differences between years. Changes in foraging effort therefore appeared to reflect differences in krill abundance and diet. The absence of small krill in the diet at the start of the 1994 season indicated that there was poor recruitment of krill around South Georgia (Priddle et al. 1988). Inter-annual variation in krill abundance is not well understood, and current theories suggest that oceanic factors affecting larval development in pack ice and changes in oceanic circulation are responsible for differences in krill recruitment around South Georgia (see review by Brierley et al. 1997).

Because lactation occurs during a highly seasonal environment, it was not clear if the seasonal pattern in foraging behaviour that was observed was the response of fur seals to changing demands of pup development or changing environmental conditions or some combination of the two. The multiple regression determined the effect of adding individual variables (either singly or in combination with multiple variables) on the total explained variance. This technique has been shown to be useful where a large number of variables are strongly correlated (Brown \& Rothery 1993).

Although there was no evidence to suggest that low krill abundance in 1994 was associated with changes in SST during the current season, SST was an important variable in explaining changes in foraging trip duration within seasons. It is perhaps not surprising that SST was important, as large scale oceanographic features appear to control the dynamics of the Southern Ocean ecosystem (Fedoulov et al. 1996). The explanatory power of SST may have reflected seasonal changes in conditions as well as the relationship between trip duration and fur seal foraging location. Females that make long foraging trips alsn travel greater distances to the NW of South Georgia (Boyd unpubl.), where they will encounter greater SSTs. Evidence for this comes from temperature records from females that abandoned their pups for more than $20 \mathrm{~d}$ in January 1994. In these cases, the mean SST far exceeded SSTs in the females' normal foraging range (Table 8).

Females did not appear to spend longer at sea in direct response to the age of the pup. Multiple regression showed that, when additional explanatory variables were added, longer trips were associated with smaller pup body mass. Although females may deliver greater amounts of milk and hence greater total energy following long foraging trips (Arnould \& Boyd 1995b, Goldsworthy 1995), the overall effect of prolonged foraging trips is to reduce pup growth rate (Lunn et al. 1993). In comparison, female foraging effort, as measured by dive frequency and percentage of time submerged, increased with pup age, suggesting that these were responses to the demands of pup growth rather than seasonal changes in the environment.

There were significant differences between male and female pups in perinatal body size, growth rate and body size at weaning. Differences in body size between sexes have previously been found in Antarctic fur seals (Doidge et al. 1984, Boyd \& McCann 1989), 
and Goldsworthy (1995) also found that male pups had higher growth rates. It could be argued that variation in foraging behaviour may also have been due to differential maternal expenditure between sexes and therefore pup sex needed to be included in regression models. However, there has been only 1 year recorded when Antarctic fur seals with male offspring made longer foraging trips, and there are no reported differences in foraging trip duration according to pup sex in any other species of otariid (see review by Lunn \& Arnould 1997). This does not mean that other aspects of foraging behaviour may not be involved in maternal investment towards offspring of different sexes. Nevertheless, equal sex ratios (Table 7 ) ensured that there was no bias towards offspring of either sex in this study.

Multiple regression also indicated that, as the duration of night increased, females made shallower and shorter dives and decreased the percentage of time submerged during foraging trips. This was predicted from the diel migration patterns of krill (see above); however, dive depth, dive duration and percentage time submerged also decreased with increasing $\mathrm{SS} /$. This may indicate a possible relationship between water temperature and the migration patterns of krill and other prey. Indeed, it has been found that where sharp thermoclines exist krill migrations are confined to the stratum between the sea surface and the upper level of the thermocline, leading to a decrease in the magnitude of migration (Godlewska 1996).

In conclusion, Antarctic fur seals appear to increase their foraging effort in response to the seasonal demands of pup development in a highly seasonal environment that is also variable across years. Variation in foraging behaviour may be also explained by patterns of SST and seasonal changes in the duration of night, both of which are important factors influencing prey availability.

Acknowledgements. We thank all the British Antarctic Survey staff at Bird Island for field assistance, in particular $\mathrm{K}$. Reid for demonstration of capture methods and diet analysis. We are also grateful to A. G. Wood and A. W. A. Murray for computer and statistical support. Thanks to J. P. Croxall for comments on an earlier draft and to 4 anonymous referees for reviewing the manuscript.

\section{LITERATURE CITED}

Arnbom TA, Lunn NJ, Boyd IL, Barton T (1992) Aging live Antarctic fur seals and southern elephant seals. Mar Mamm Sci 8:37-43

Arnould JPY, Boyd IL (1995a) Inter- and intra-annual variation in milk composition in Antarctic fur seals (Arctocephalus gazella). Physiol Zool 68:1164-1180

Arnould JPY, Boyd IL (1995b) Temporal patterns of milk production in Antarctic fur seals (Arctocephalus gazella).
J Zool Lond 237:1-12

Arnould JPY, Boyd IL, Socha DG (1996) Milk consumption. and growth efficiency in Antarctic fur seal (Arctocephalus gazella) pups. Can J Zool 74:254-266

Boyd IL (1996) Temporal scales of foraging in a marine predator. Ecology $77426-434$

Boyd IL, Arnould JPY, Barton T, Croxall JP (1994) Foraging behaviour of Antarctic fur seals during periods of contrasting prey abundance. J Anim Ecol 63:703-713

Boyd IL, Croxall JP (1992) Diving behaviour of lactating Antarctic fur seals. Can J Zool 70:919-928

Boyd IL, Croxall JP, Lunn NJ, Reid K (1995) Population. demography of Antarctic fur seals: the costs of reproduction and implications for life histories. J Anim Ecol 64: 505-518

Boyd IL, Lunn NJ, Barton T (1991) Time budgets and foraging characteristics of lactating Antarctic fur seals. J Anim Ecol 60.577-592

Boyd IL, Lunn NJ, Rothery P, Croxall JP (1990) Age distribution of breeding female Antarctic fur seals in relation to changes in population growth rate. Can J Zool 68: 2209-2213

Boyd IL, McCafterty DJ, Reid K, Tayior $R$, Walker TR (in press) Dispersal of male and female Antarctic fur seals (Arctocephalus gazella). Can J Fish Aquat Sci 55

Boyd IL, MCCafferty DJ, Walker TR (1997) Variation in foraging effort by lactating Antarctic fur seals: response to simulated increased foraging cusis. Dehẩy Ecol Sociobiol 40: $135-144$

Boyd IL, McCann TS (1989) Pre-natal investment in reproduction by female Antarctic fur seals. Behav Ecol Sociobiol 24:377-385

Brierley AS, Watkins JL (1996) Acoustic targets at South Georgia and the South Orkney Islands during a season of krill scarcity. Mar Ecol. Prog Ser 138:51-61

Brierley AS, Watkins JL, Murray AWA (1997) Interannual variability in krill abundance at South Georgia. Mar Ecol Prog Ser 150:87-98

Brown D, Rothery P (1993) Models in biology: mathematics, statistics and computing. John Wiley \& Sons, Chichester

Clutton-Brock TH, Guiness FE, Albon SD (1982) Red deer Behaviour and ecology of two sexes. Edinburgh University Press, Edinburgh

Costa DP, Croxall JP, Duck CD (1989) Foraging energetics of Antarctic fur seals in relation to changes in prey availability. Ecology 70:596-606

Croxall JP, Everson I, Kooyman GL, Ricketts C, Davis RW (1985) Fur seal diving behaviour in relation to vertical distribution of krill. J Anim Ecol 54:1-8

Croxall JP, McCann TS, Prince PA, Rothery P (1988) Reproductive performance of seabirds and seals at South Georgia and Signy Island. South Orkney Islands 1976-1987: implications for Southern Ocean monitoring studies. In: Sahrhage D (ed) Antarctic ocean and resource variability. Springer-Verlag, Berlin, p 261-285

Croxall JP, Pilcher MN (1984) Characteristics of krill Euphausia superba eaten by Antarctic fur seals Arctocephalus gazella at South Georgia. Br Antarct Surv Bull 63:117-125

David JHM, Rand RW (1986) Attendance behaviour of South African fur seals. In: Gentry RL, Kooyman GL (eds) Fur seals: maternal strategies on land and at sea. Princeton University Press, Princeton, p 126-141

Doidge DW, Croxall JP (1985) Diet and energy budget of the Antarctic fur seal, Arctocephalus gazella, at South Georgia. In: Siegfried WR, Condy PR, Laws RM (eds) Antarctic nutrient cycles and food webs. Springer-Verlag, Berlin, p $543-550$ 
Doidge DW, Croxall JP, Ricketts C (1984) Growth rate of Antarctic fur seal Arctocephalus gazella at South Georgia. Polar Biol 9:155-160

Doidge DW, McCann TS, Croxall JP (1986) Attendance behaviour of Antarctic fur seals. In: Gentry RL, Kooyman GL (eds) Fur seals: maternal strategies on land and at sea. Princeton University Press, Princeton, p 102-114

Everson I (1983) Variations in vertical distribution and density of krill swarms in the vicinity of South Georgia. Mem Natl Inst Polar Res 27:84-92

Fedoulov PP, Murphy E, Shulgovsky KE (1996) Environmentkrill relations in the South Georgia marine ecosystem. CCAMLR SCi 3:13-30

Gentry RL, Holt JR (1982) Equipment and techniques for handling northern fur seals. NOAA Tech Rep NMFS SSRF No. 758, National Marine Fisheries Service Seattle, Washington

Gentry RL, Holt JR (1986) Attendance behaviour of northern fur seals. In: Gentry RL, Kooyman GL (eds) Fur seals: maternal strategies on land and at sea. Princeton University Press, Princeton, p 41-60

Gentry RL, Kooyman GL (1986) Introduction. In: Gentry RL, Kooyman GL (eds) Fur seals: maternal strategies on land and at sea. Princeton University Press, Princeton, p 3-27

Gentry RL, Kooyman GL, Goebel ME (1986) Feeding and diving behaviour of northern fur seals. In: Gentry RL, Kooyman GL (eds) Fur seals: maternal strategies on land and at sea. Princeton University Press, Princeton, p 61-78

Godlewska M (1996) Vertical migrations of krill (Euphausia superba Dana). Pol Arch Hydrobiol 43:9-63

Goebel ME (1988) Duration of feeding trips and age-related reproductive success of lactating females. In: Kozloff $P$, Kajimura $\mathrm{H}$ (eds) Fur seal investigations, 1985. WA NOAA. Technical Memorandum NMFS-F/NWC-146, US Departmint of Counuerce, ivationai Manne Fisheries Service, Northwest and Alaska Fisheries Center, Seattle, p 28-33

Goldsworthy SD (1995) Differential expenditure of maternal resources in Antarctic fur seals, Arctocephalus gazella, at Heard Island, southern Indian Ocean. Behav Ecol 6: $218-228$

Illius AW, Gordon IJ (1993) Diet selection in mammalian her-

Editorial responsibility: Otto Kinne (Editor),

Oldendorf/Luhe, Germany bivores: constraints and tactics. In: Hughes RN (ed) Diet selection. An interdisciplinary approach to foraging behaviour. Blackwell, Oxford, p 157-181

Lunn NJ, Arnould JPY (1997) Maternal investment in Antarctic fur seals: evidence for equality in the sexes? Behav Ecol Sociobiol 40:351-362

Lunn NJ, Boyd IL, Barton T, Croxall JP (1993) Factors affecting the growth rate and mass at weaning of Antarctic fur seals at Bird Island, South Georgia. J Mammal 74:908-919

Lunn NJ, Boyd IL, Croxall JP (1994) Reproductive performance of female Antarctic fur seals: the influence of age, breeding experience, environmental variation and individual quality. J Anim Ecol 63:827-840

Priddle J, Croxall JP, Everson I, Heywood RB, Murphy EJ, Prince PA, Sear CB (1988) Long-term fluctuations in mesoscale abundance of krill-a discussion of possible causes. In: Sahrhage D (ed) Antarctic ocean and resource variability. Springer-Verlag, Berlin, p 169-182

Reid K, Arnould JPY (1996) The diet of Antarctic fur seals Arctocephalus gazella during the breeding season at South Georgia. Polar Biol 16:105-114

Reynolds RW, Smith TM (1994) Improved global sea surface temperature analysis. J Clim 7:929-948

Trillmich F (1986) Attendance behaviour of Galapagos fur seals. In: Gentry RL, Kooyman GL (eds) Fur seals: maternal strategies on land and at sea. Princeton University Press, Princeton, p 168-185

Trillmich F, Ono KA, Costa DP, DeLong RL, Feldkamp SD, Francis JM, Gentry RL, Heath CB, LeBoeuf BJ, Majiluf P, York AE (1991) The effects of El Niño on pinniped populations in the Eastern Pacific. In: Trillmich F, Ono KA (eds) Pinnipeds and El Niño. Responses to environmental stress. Ecological Studies 88, Springer-Verlag, Berlin, p 247-270

Wainwright PC (1994) Functional mornhnlogy as a tool in ecological research. In: Wainwright PC, Reilly SM (eds) Ecological morphology. Integrative organismal biology. University Chicago Press, London, p 42-59

Walker BG, Boveng PL (1995) Effects of time-depth recorders on maternal foraging and attendance behaviour of Antarctic fur seals (Arctocephalus gazella). Can J Zool 73: $1538-1544$

Submitted: October 23, 1997; Accepted: March 24, 1998

Proofs received from author(s): May 15, 1998 